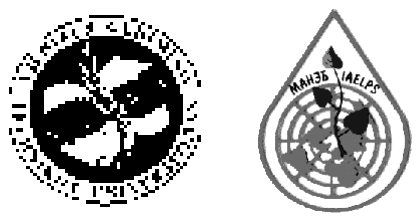

\title{
EVALUATION OF RADIONUCLIDE CONCENTRATION IN THE BOTTOM GROUND OF WATER RESERVOIRS AND WATERSIDE SOIL
}

\author{
Dainius Jasaitis, Milda Pečiulienė, Aloyzas Girgždys \\ Laboratory of Nuclear Hydrophysics, Vilnius Gediminas Technical University, \\ Saulètekio al. 11, LT-10223 Vilnius-40, Lithuania.E-mail: algi@fm.vtu.lt
}

Received 13 May 2004; accepted 26 May 2004

\begin{abstract}
The paper covers evaluation of concentration of natural and artificial radionuclides found in the soil and the bottom ground of water reservoirs. It was measured that radionuclide concentration in the soil is bigger than that in the bottom ground of water reservoirs $\left({ }^{40} \mathrm{~K}\right.$ concentration in the ground equals $500 \mathrm{~Bq} / \mathrm{kg}$, in the bottom ground - about $200 \mathrm{~Bq} / \mathrm{kg}$ ). Positive correlation was set among all types of radioisotopes. Correlation quotient between artificial radionuclide ${ }^{137} \mathrm{Cs}$ and natural radionuclides amounts to zero.
\end{abstract}

Keywords: ionizing radiation, natural radionuclides, specific activity, bottom ground, soil.

\section{Introduction}

Most widely spread natural radionuclides are from the family of Uranium $\left({ }^{238} \mathrm{U}\right)$, Thorium $\left({ }^{232} \mathrm{Th}\right)$, and Actinium $\left({ }^{235} \mathrm{Ac}\right)$ and Kalium. ${ }^{137} \mathrm{Cs}$ dominates among durable artificial gamma radiators. It takes 300 years for it to fragment completely. Due to that it migrates in various geospheres and biological links. The biggest part of ${ }^{137} \mathrm{Cs}$ is accumulated in the upper layers of the soil and forest floor [1]. Radioactive substances emitted into the atmosphere become part of the general air circulation and moves all over the earth. Radioactive substances precipitated on the earth surface are either lifted again by the wind or penetrate into the ground. Then radioactive substances are absorbed by plants through their roots and finally reach human organism.

Nuclear explosions and the consequences of Chernobyl Nuclear Power Plant accident influence the Lithuanian environment. Radioactive substances are still carried from the most polluted areas of the Ukraine and Byelorussia. Besides, nuclear industry objects threaten a real danger of possible accidents during which a certain amount of radioactive substances can be emitted into the atmosphere.

Nowadays much attention is paid to the issues of radionuclide behavior in water reservoirs $[2,3]$. The feature of open water reservoirs to accumulate pollution carried by outflow should cause worries because these water reservoirs are widely used for human needs.

Search for radionuclide pollution sources measur- ing equivalent dose rate was carried out above Vilnius open water reservoirs using a mobile method [4] (applying GPS system). It is rated [4] that the values of these quantities equal from $10 \mathrm{nSv} / \mathrm{h}$ to $85 \mathrm{nSv} / \mathrm{h}$. It is noticed that the quantities measured above water are much smaller than an average equivalent dose rate above the ground surface. For a more detailed investigation the radioisotope composition of surroundings had to be evaluated. Therefore, the quantity of natural and artificial radionuclides found in rivers, streams, lakes, ponds and other water reservoirs and the concentration level of separate gamma active radionuclides were measured.

\section{Investigation methods}

Gamma spectrometer analysis was used to measure concentration of activities of separate radionuclides. This paper analyses water reservoir bottom samples taken in Vilnius lakes, such as Antavilis, Balžis, Gulbinai, Gelužè, Balsys, Skarbelelis, Juodis, Tapeliai and Dvarčionys and the Neris river and the nearby non-arable field. Fig 1 depicts the location of lakes in Antaviliai locality.

Bottom ground was taken with a special recipient made for this purpose. While taking samples a metal ring $15 \mathrm{~cm}$ in diameter and $5 \mathrm{~cm}$ in height was hammered into the ground, the ground was separated from the bottom with a spade. Samples were carried to a laboratory in plastic bags. Samples were weighted in the laboratory and put into $200 \mathrm{ml}$ containers.

Ground sample activity was measured using a 


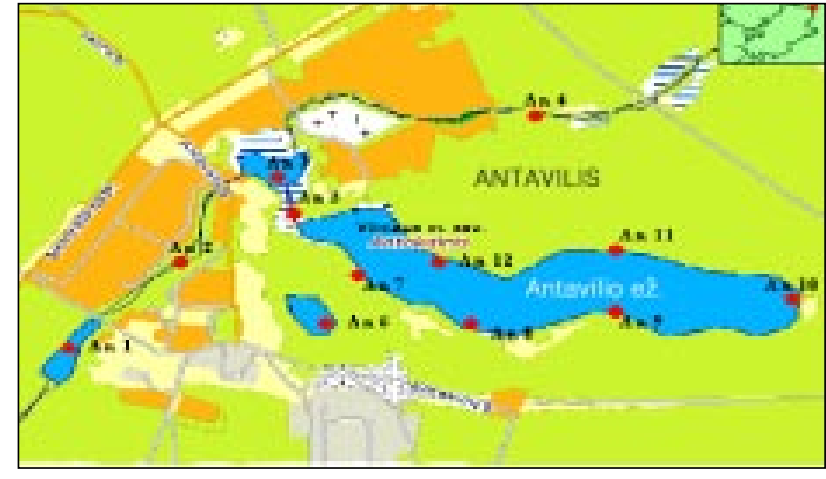

Fig 1. Location of sample lakes in Antaviliai locality (An1An12)

gamma spectrometer system (CANBERRA) with a semiconductor HPGe detector (resolution $2 \mathrm{keV}$, effectiveness $15 \%$ ) for evaluating the specific activity of natural and artificial radionuclides.

The detector is characterized by a big resolution because it is refrigerated with liquid nitrogen. The equipment is characterized by a direct signal, wide energy interval, undelicacy of impulse amplitude for impulse calculation speed, high speed of impulse increasing, undelicacy for magnet fields.

The spectrometer is calibrated for a standard 200 $\mathrm{ml}$ container. Solid ${ }^{152} \mathrm{Eu}+{ }^{137} \mathrm{Cs}$ etalons of a different density and familiar activity were used for calibration.

Specific activity of the main gamma radiation in the ground was measured applying 24-72 hour expositions of sample measurement. Radionuclides were identified according to the following energy lines: ${ }^{226} \mathrm{Ra}-$ $186 \mathrm{keV},{ }^{212} \mathrm{~Pb}-239 \mathrm{keV},{ }^{214} \mathrm{~Pb}-295 \mathrm{keV},{ }^{214} \mathrm{~Pb}-$ $352 \mathrm{keV},{ }^{208} \mathrm{Tl}-583 \mathrm{keV},{ }^{214} \mathrm{Bi}-609 \mathrm{keV},{ }^{137} \mathrm{Cs}-$ $662 \mathrm{keV},{ }^{228} \mathrm{Ac}-911 \mathrm{keV},{ }^{214} \mathrm{Bi}-1120 \mathrm{keV},{ }^{40} \mathrm{~K}-$ $1460 \mathrm{keV}$.

The background was constantly measured during the estimation procedure. The background level fluctuated little. Fluctuations ${ }^{40} \mathrm{~K}$ composed less than $4 \%$ of the signal size.

\section{Measurement results}

The concentration of natural and artificial ${ }^{226} \mathrm{Ra}$, ${ }^{214} \mathrm{~Pb},{ }^{214} \mathrm{Bi},{ }^{228} \mathrm{Ac},{ }^{212} \mathrm{~Pb},{ }^{208} \mathrm{Tl},{ }^{40} \mathrm{~K}$ and ${ }^{137} \mathrm{Cs}$ was measured.

Fig 2 depicts $\gamma$ spectrum got with a semiconductor spectrometer. Here is a spectrum figure from the Balsio lake sample (Ba4) (exposition of 24 hours).

Peaks of the gamma energetic line of a separate radionuclide are clearly seen. The peak of a natural radionuclide ${ }^{40} \mathrm{~K}$ is seen best. Equivalent dose rate caused by this radionuclide radiation approximately composes $33 \%$ of the value of general equivalent dose rate in the earth surface air [5].

From natural radionuclides, the activity of ${ }^{40} \mathrm{~K}$ in the ground is the biggest. This can be seen in Fig 3. In all the diagrams (Figs 3-5) the value of the specific

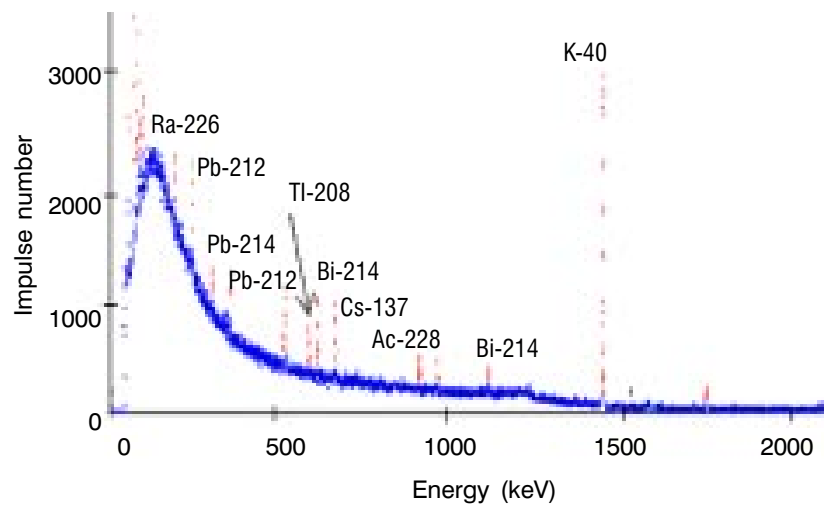

Fig 2. Primary energy gamma spectrum of a sample (Ba4)

activity of ${ }^{40} \mathrm{~K}$ is much bigger than others. Due to this it is reduced 10 times in the figure $(\mathrm{A} / 10)$.

The quantity of ${ }^{40} \mathrm{~K}$ and other natural radionuclide

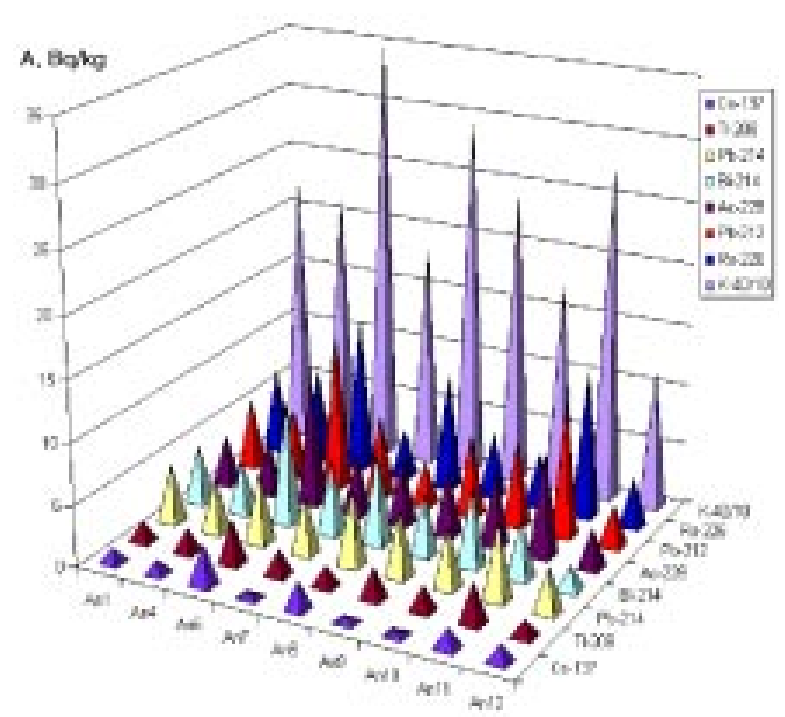

Fig 3. Radionuclide concentration $(\mathrm{Bq} / \mathrm{kg})$ in Antavilis locality (An1-An12 samples) in the lake bottom ground

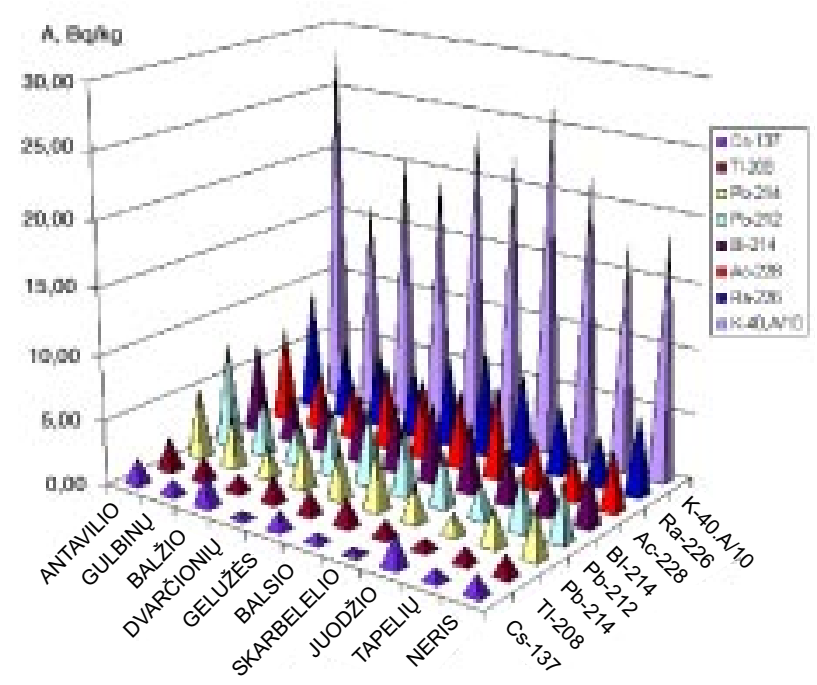

Fig 4. Radionuclide concentration in the water reservoir bottom ground $(\mathrm{Bq} / \mathrm{kg})$ 


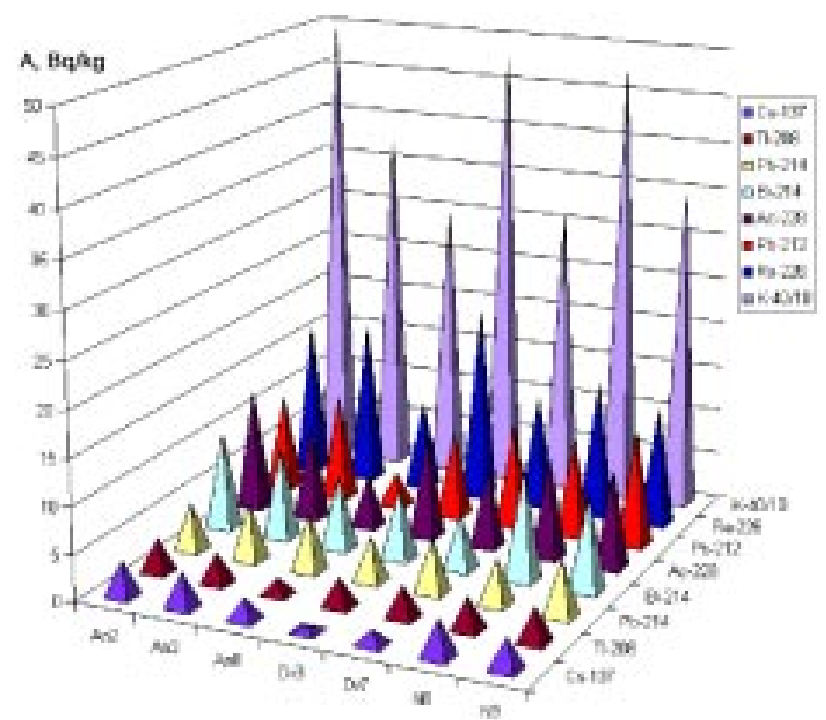

Fig 5. Radionuclide concentration in the soil $(\mathrm{Bq} / \mathrm{kg})$

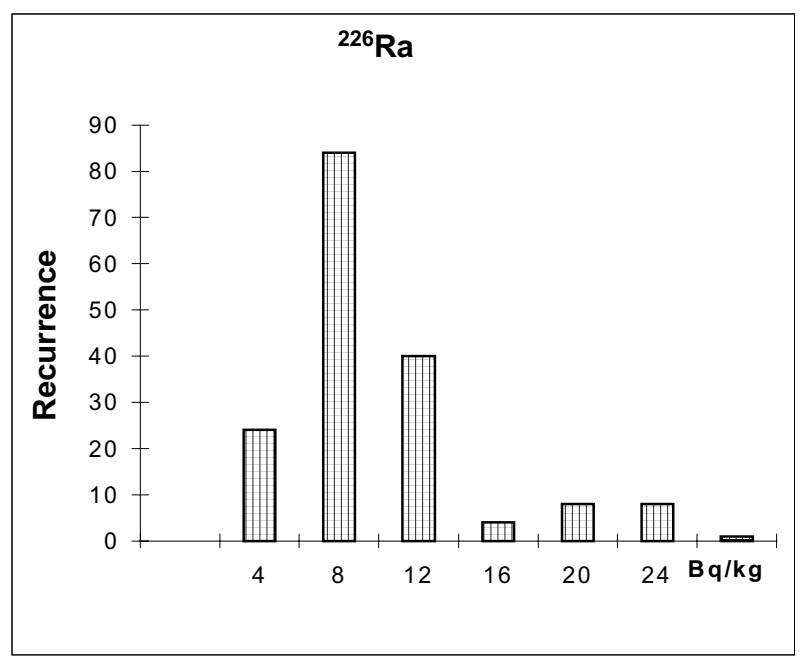

Fig 6. Concentration recurrence frequency of radionuclide ${ }^{226} \mathrm{Ra}$ in water reservoir bottom ground samples

in the samples fluctuated to three times. This could happen due to different ground composition and different quantities of settling. Especially big fluctuations occurred in artificial radionuclide ${ }^{137} \mathrm{Cs}$ (to ten times).

Fig 4 depicts a diagram showing distribution meanings of radionuclide concentration in the bottom ground of all the studied water reservoirs, Fig 5 - in the soil.

The provided results show that the specific activity of radionuclides that are in the soil is bigger than that in the water reservoir bottom ground. The most frequent value of the specific activity of ${ }^{40} \mathrm{~K}$ in the soil is be about $400-500 \mathrm{~Bq} / \mathrm{kg}$, and about $200 \mathrm{~Bq} / \mathrm{kg}$ in the water reservoir bottom ground. It is smaller than an average specific activity of the same radionuclide in the soil of Central Europe and Lithuania. [5, 6]. This can be explained that part of ${ }^{40} \mathrm{~K}$ in one or another form melts in water and its quantity in the bottom ground reduces. The value of the specific activity of artificial radionuclide ${ }^{137} \mathrm{Cs}$ both in the soil and in the water reservoir bottom ground is $0,1-5 \mathrm{~Bq} / \mathrm{kg}$.

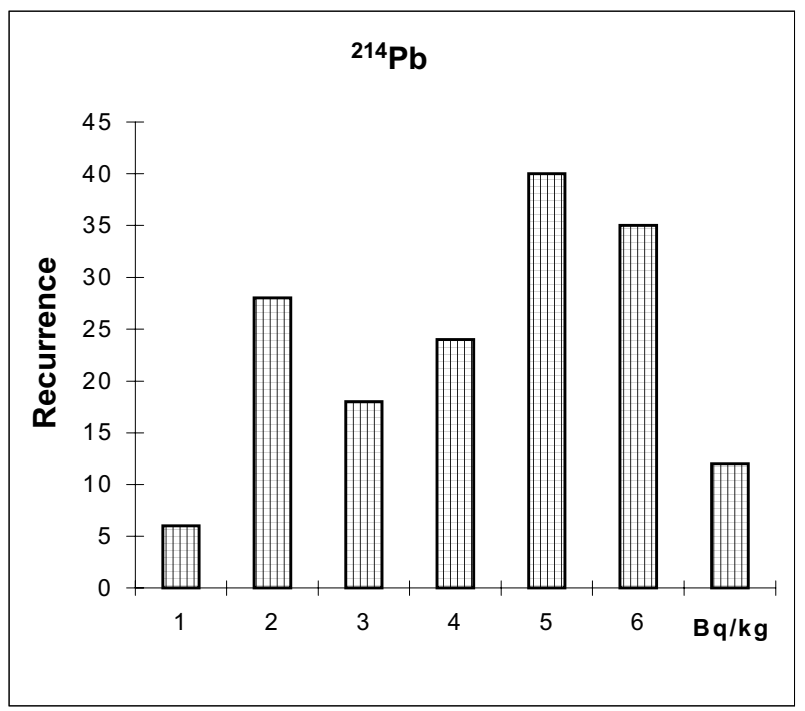

Fig 7. Concentration recurrence frequency of radionuclide ${ }^{214} \mathrm{~Pb}$ in water reservoir bottom ground samples

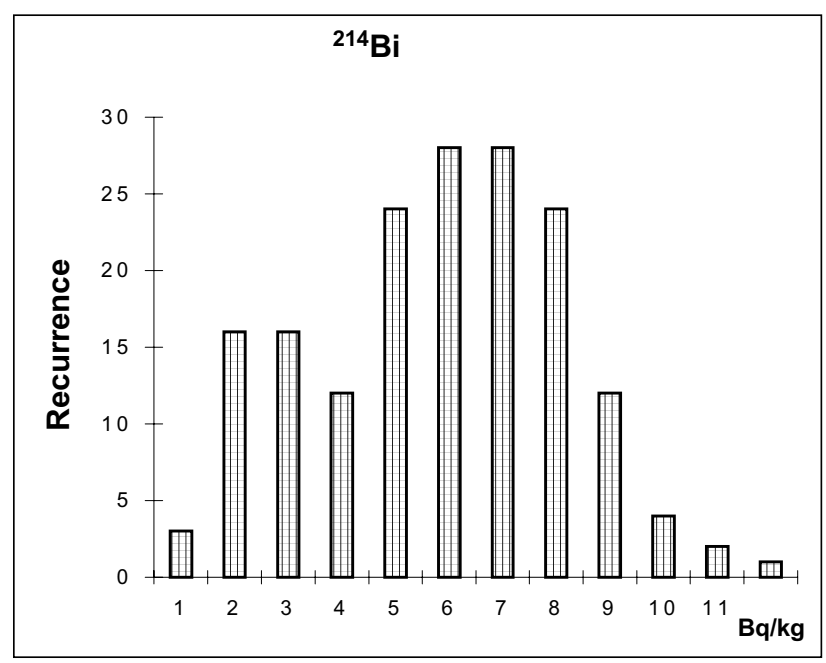

Fig 8. Concentration recurrence frequency of radionuclide ${ }^{214} \mathrm{Bi}$ in water reservoir bottom ground samples

According to the measurements, there was no complete radioactive balance in the samples among separate radioactive families.

The concentration distribution of separate radioisotope activity characterizes distribution frequency (Fig 6-13).

The specific activity of the representatives of Uranium - Radium family ${ }^{226} \mathrm{Ra},{ }^{214} \mathrm{~Pb},{ }^{214} \mathrm{Bi}$ is distributed according to the normal bimodal law (Figs 6-8). The distribution mode maximum of ${ }^{226} \mathrm{Ra}$ is about $8 \mathrm{~Bq} / \mathrm{kg}$ and $20 \mathrm{~Bq} / \mathrm{kg}$, of ${ }^{214} \mathrm{~Pb}$ and ${ }^{214} \mathrm{Bi}$ - about $2-3 \mathrm{~Bq} / \mathrm{kg}$ and $6-7 \mathrm{~Bq} / \mathrm{kg}$. The quantity of ${ }^{214} \mathrm{~Pb},{ }^{214} \mathrm{Bi}$ in the samples is smaller than that of primary ${ }^{226} \mathrm{Ra}$. This is due to the fact that transitional Radon ${ }^{222} \mathrm{Rn}$ according to split line is inert gas which effectively diffuse from ground into water and into the atmosphere, that is why only part of it is left in the ground. The concentration of measured radionuclides ${ }^{214} \mathrm{~Pb}$ and ${ }^{214} \mathrm{Bi}$ reflects only Radon quantity in a sample that appears during transportation and spectrum analysis. The quantity of these 
radionuclides in the ground cannot be estimated before sample taking due to their short split half-life. They manage to disintegrate during sample transportation. Interesting results of the investigation are the following: bimodal distribution of ${ }^{226} \mathrm{Ra},{ }^{214} \mathrm{~Pb}$ and ${ }^{214} \mathrm{Bi}$ concentration in all the water reservoirs (Figs 6-8). One of possible explanations could be two more distinguished ground compositions, however, this hypothesis needs additional investigations.

The specific activity of thorium radioactive disintegration group members $\left({ }^{228} \mathrm{Ac},{ }^{212} \mathrm{~Pb},{ }^{208} \mathrm{Tl}\right)$ is distrib-

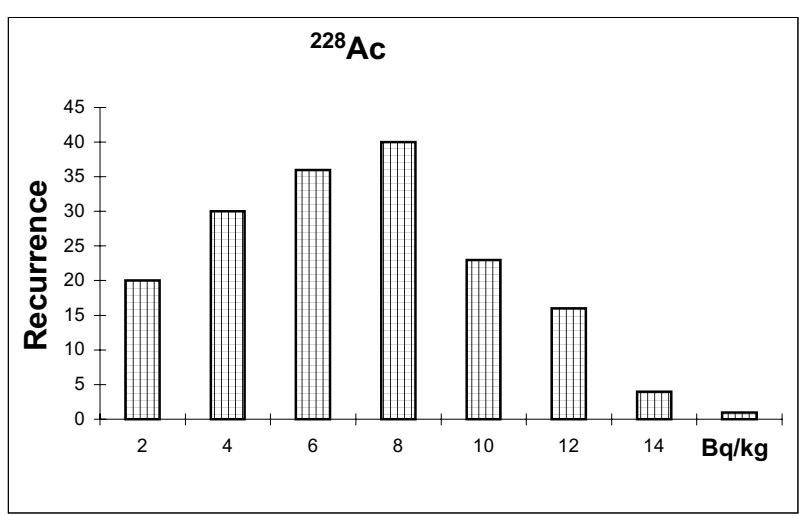

Fig 9. Concentration recurrence frequency of radionuclide ${ }^{228} \mathrm{Ac}$ in water reservoir bottom ground samples

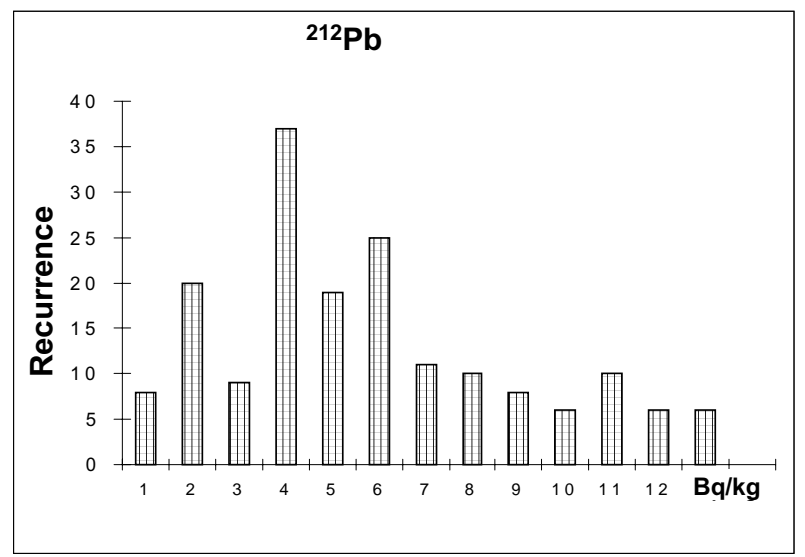

Fig 10. Concentration recurrence frequency for ${ }^{212} \mathrm{~Pb}$ radionuclide in water reservoir bottom ground samples

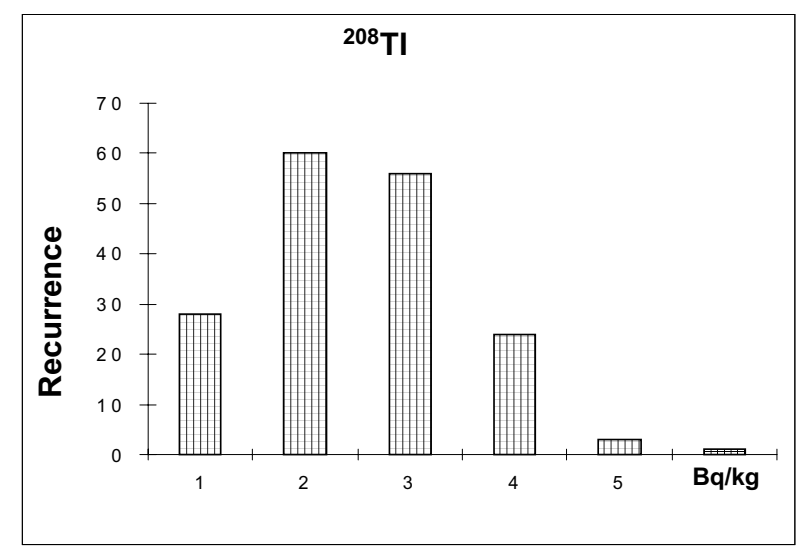

Fig 11. Concentration recurrence frequency for ${ }^{208} \mathrm{Tl}$ radionuclide in water reservoir bottom ground samples uted according to a single-mode law (Figs 9-11).

These radionuclides are not in radioactive equilibrium either. The maximum of the specific activity of recurrence frequency of an initial member in accordance with a radioactive disintegration group row ${ }^{228} \mathrm{Ac}$ is about $7-8 \mathrm{~Bq} / \mathrm{kg}$. It is close to the first mode of ${ }^{226} \mathrm{Ra}$ distribution. The specific activity values are mostly $4 \mathrm{~Bq} / \mathrm{kg}$ for ${ }^{212} \mathrm{~Pb}$ and $2-3 \mathrm{~Bq} / \mathrm{kg}$ for ${ }^{208} \mathrm{Tl}$.

${ }^{40} \mathrm{~K}$ does not belong to any disintegration group. This natural radionuclide is the most active. Its specific activity recurrence is close to the normal law (Fig 12). The specific activity value of ${ }^{40} \mathrm{~K}$ is mostly $200 \mathrm{~Bq} / \mathrm{kg}$.

The increase of concentration recurrence is about $500 \mathrm{~Bq} / \mathrm{kg}$ (Fig 12). This is due to separate anthropogenic influence.

Soils and pastures near water reservoirs are fertilized with potassium. Fertilizers get into water reservoirs, therefore a big increase of ${ }^{40} \mathrm{~K}$ specific activity was measured. Thus ${ }^{40} \mathrm{~K}$ activity concentration can be the measure of water reservoir anthropogenic load.

${ }^{137} \mathrm{Cs}$ belongs to artificial anthropogenic radionuclide class. Its statistic distribution of specific activity recurrence frequency (Fig 13) is greatly different from the distribution of natural radionuclides.

The concentration recurrence of this nuclide corresponds to the exponential law:

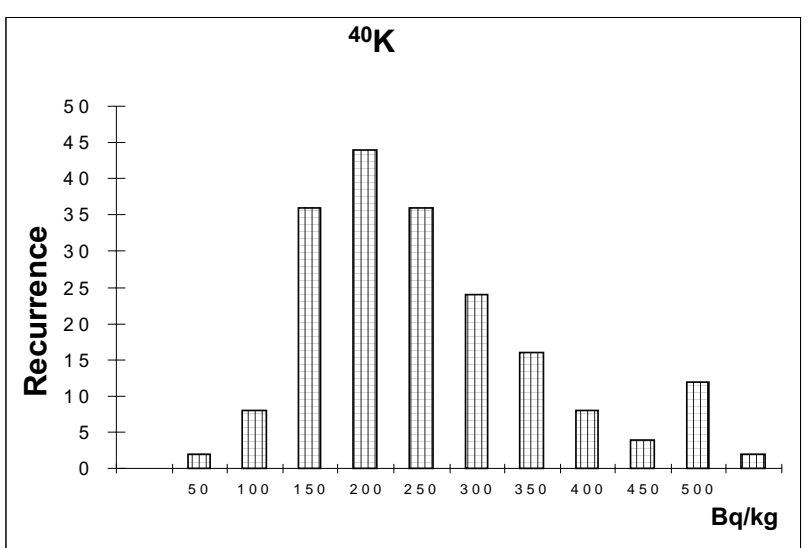

Fig 12. Concentration recurrence frequency of ${ }^{40} \mathrm{~K}$ radionuclide in water reservoir bottom ground samples

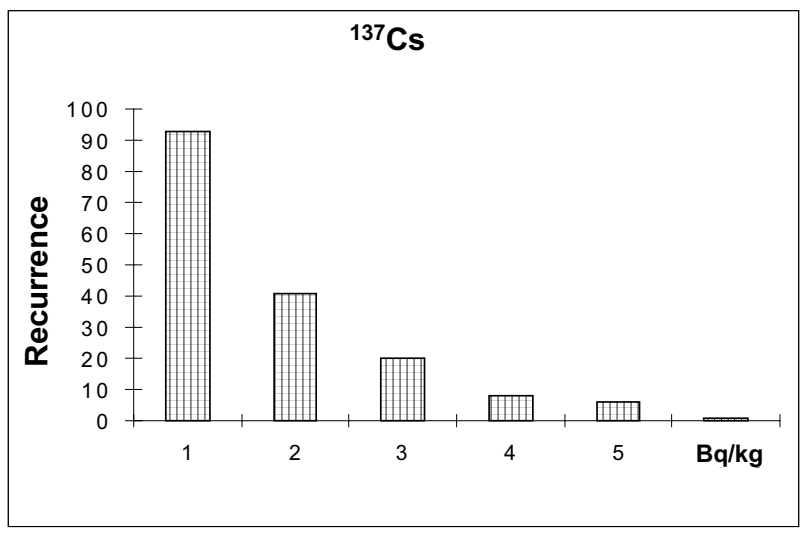

Fig 13. Concentration recurrence frequency of ${ }^{137} \mathrm{Cs}$ radionuclide in water reservoir bottom ground samples 


$$
\mathrm{f}(n)=N \exp (-k C)
$$

where $N$ - number of samples, $C$ - concentration of nuclide, $\mathrm{Bq} / \mathrm{kg}, k$ - coefficient (for investigated water reservoirs equal to 0,83 ).

There exists the greatest probability to find that the radionuclide is less than $5 \mathrm{~Bq} / \mathrm{kg} .{ }^{137} \mathrm{Cs}$ has dispersed in Lithuania due to the Chernobyl Nuclear Power Plant accident. The spread of ${ }^{137} \mathrm{Cs}$ in water reservoirs differs from that inside water reservoirs.

Correlation analysis of all the obtained radioisotope specific activity data from water reservoir bottom ground was performed (Table).

Positive correlation between all the natural radioisotopes was established. Not all the radioisotopes of one group are closely connected, for example, the correlation coefficient of ${ }^{226} \mathrm{Ra}$ and ${ }^{214} \mathrm{~Pb}$ data is only 0,43 .

Correlation coefficients among ${ }^{226} \mathrm{Ra},{ }^{228} \mathrm{Ac}$ and ${ }^{40} \mathrm{~K}$ are large positive numbers. ${ }^{214} \mathrm{~Pb}$ and ${ }^{214} \mathrm{Bi}$ and ${ }^{212} \mathrm{~Pb}$ and ${ }^{208} \mathrm{Tl}$ arise after ${ }^{226} \mathrm{Ra}$ and ${ }^{228} \mathrm{Ac}$ radioisotope disintegration. Because of radioisotope formation chain has the inert gas phase, radioactive equilibrium is not always possible due to volatile gas. Therefore, the correlation coefficients between the radioisotope quantity of the same radioactive disintegration order are not close to 1 .

Distribution between natural radioisotopes is determined by natural and frequently geological processes which are the reason of conditional resilient connection between them.

Correlation coefficients are very different from an artificial radionuclide ${ }^{137} \mathrm{Cs}$ with other natural radionuclides.

Artificial radioisotopes are distributed very dissimilarly. Short-term meteorological conditions predetermined the distribution of artificial radionuclides after nuclear experiments and the Chernobyl Nuclear Power Plant accident.

It is established that falls due to nuclear experiments and after the Chernobyl Nuclear Power Plant accident can make $1 \%$ of all ionizing radionuclide power in $\mathrm{Eu}-$ rope. The ionizing radiation influence of an artificial radionuclide ${ }^{137} \mathrm{Cs}$ is less than $0,1 \%$ in open water reservoirs of Vilnius.

\section{Conclusions}

The concentrations of radionuclides ${ }^{226} \mathrm{Ra},{ }^{214} \mathrm{~Pb}$, ${ }^{214} \mathrm{Bi},{ }^{228} \mathrm{Ac},{ }^{212} \mathrm{~Pb},{ }^{208} \mathrm{Tl},{ }^{40} \mathrm{~K}$ and ${ }^{137} \mathrm{Cs}$ were estimated in open water reservoirs. Specific activity of representatives of Uranium family: ${ }^{226} \mathrm{Ra},{ }^{214} \mathrm{~Pb},{ }^{214} \mathrm{Bi}$ is distributed according to the normal bimodal law. Maximum of distribution mode of ${ }^{226} \mathrm{Ra}$ is about $8 \mathrm{~Bq} / \mathrm{kg}$ and $20 \mathrm{~Bq} /$ $\mathrm{kg}$. Maximum of ${ }^{214} \mathrm{~Pb}$ and ${ }^{214} \mathrm{Bi}$ is about $2-3 \mathrm{~Bq} / \mathrm{kg}$ and $6-7 \mathrm{~Bq} / \mathrm{kg}$. Specific activity of the representatives of Thorium family ${ }^{228} \mathrm{Ac},{ }^{212} \mathrm{~Pb},{ }^{208} \mathrm{Tl}$ is distributed according to a single-mode law (maximum about 7-8 Bq/ $\mathrm{kg}$ ). An average specific activity of ${ }^{40} \mathrm{~K}$ in the bottom ground is about $200 \mathrm{~Bq} / \mathrm{kg}$. It is smaller than an average specific activity of the same radionuclide found in the Lithuanian soil, i e about $540 \mathrm{~Bq} / \mathrm{kg}$.

The statistical distribution of occurrence frequency of the specific activity of an anthropogenic radionuclide ${ }^{137} \mathrm{Cs}$ differs much from the distribution of natural radioisotopes. The biggest part of the specific activity of ${ }^{137} \mathrm{Cs}$ in the samples was about $5 \mathrm{~Bq} / \mathrm{kg}$.

It is measured that correlation among all the natural radioisotopes is positive. High positive interdependent relation correlation quotients (about 0,8 ) are among natural durable radionuclides ${ }^{226} \mathrm{Ra},{ }^{228} \mathrm{Ac}$ and ${ }^{40} \mathrm{~K}$.

Correlation quotients of an artificial radionuclide ${ }^{137} \mathrm{Cs}$ differ much from other natural radionuclides. They are close to zero (positive and negative).

\section{References}

1. WHO working group for health hazards from radiocesium following the Chernobyl nuclear accident. Journal of Environmental Radioactivity, No 10, 1989, p 257-295.

2. Hakanson, L. A compilation of empirical data and variations in data concerning radiocesium in water, sediments and fish in European lakes after Chernobyl. Journal of Environmental Radioactivity, No 44, 1999, p 21-42.

3. Konoplev, A.; Kaminski, S. et al. Comparative study of ${ }^{137} \mathrm{Cs}$ partitioning between solid and liquid phases in Lake Constance, Lugano and Vorsee. Journal of Environmental Radioactivity, No 58, 2002, p 1-11.

4. Pečiulienè, M; Jasaitis, D; Grigaliūnienè-Vonsevičienè, G.; Girgždys, A. Equivalent dose rate of ionizing radiation above water reservoirs in Vilnius. Environmental Engineer-

Correlation among radionuclide concentrations in the water reservoirs bottom ground

\begin{tabular}{|c|c|c|c|c|c|c|c|c|}
\hline & ${ }^{226} \mathbf{R a}$ & ${ }^{214} \mathbf{P b}$ & ${ }^{214} \mathbf{B i}$ & ${ }^{228} \mathbf{A c}$ & ${ }^{212} \mathbf{P b}$ & ${ }^{208} \mathbf{T l}$ & ${ }^{40} \mathbf{K}$ & ${ }^{137} \mathbf{C s}$ \\
\hline${ }^{226} \mathbf{R a}$ & 1,00 & & & & & & & \\
\hline${ }^{214} \mathbf{P b}$ & 0,43 & 1,00 & & & & & & \\
\hline${ }^{214} \mathbf{B i}$ & 0,67 & 0,54 & 1,00 & & & & & \\
\hline${ }^{228} \mathbf{A c}$ & 0,70 & 0,62 & 0,81 & 1,00 & & & & \\
\hline${ }^{212} \mathbf{P b}$ & 0,45 & 0,65 & 0,47 & 0,66 & 1,00 & & & \\
\hline${ }^{208} \mathbf{T l}$ & 0,57 & 0,84 & 0,65 & 0,76 & 0,81 & 1,00 & & \\
\hline${ }^{40} \mathbf{K}$ & 0,82 & 0,29 & 0,74 & 0,79 & 0,47 & 0,49 & 1,00 & \\
\hline${ }^{137} \mathbf{C s}$ & 0,11 & $-0,30$ & 0,10 & $-0,04$ & $-0,01$ & $-0,15$ & 0,18 & 1,00 \\
\hline
\end{tabular}


ing and Landscape Management, Vol XII, No 2. Vilnius, 2004, p 53-57.

5. Konstantinova, M.; Butkus, D. Estimation of exterior equivalent dose rate caused by natural origin gamma radiation being in soil. Health Sciences, No 3. Vilnius: Technika, 2003, p 50-54 (in Lithuanian).

6. Malczewski, D.; Teper, L. and Dorda, J. Assessment of natural and anthropogenic radioactivity levels in rocks and soils in the environs of Swieradow Zdroj in Sudetes, Poland, by in situ gamma-ray spectrometry. Journal of Environmental Radioactivity, Vol 73, Issue 3, 2004, p 233-245.

\section{RADIONUKLIDŲ KONCENTRACIJU巳 VANDENS TELKINIU DUGNO GRUNTE BEI KRANTO DIRVOJE IVERTINIMAS}

\section{Jasaitis, M. Pečiulienė, A. Girgždys}

\section{S a n tra u k a}

Darbe îvertintos gamtinès bei dirbtinès kilmès radionuklidų, esančių dirvoje bei vandens telkinių dugno grunte, koncentracijos. Nustatyta, kad daugumos radionuklidų koncentracijos dirvoje yra didesnès nei vandens telkinių dugno grunte $\left({ }^{40} \mathrm{~K}\right.$ koncentracija dirvoje vidutiniškai siekia $500 \mathrm{~Bq} / \mathrm{kg}$, o dugno grunte - apie $200 \mathrm{~Bq} / \mathrm{kg}$ ). Nustatytas teigiamas koreliacinis ryšys tarp visų gamtinès kilmès radioizotopų, o dirbtinio radionukli- do ${ }^{137} \mathrm{Cs}$ ir gamtinès kilmès radionuklidu koreliacijos koeficientai artimi nuliui.

Raktažodžiai: jonizuojančioji spinduliuotè, gamtinès kilmès radionuklidai, savitasis aktyvumas, dugno gruntas.

\section{ОПРЕДЕЛЕНИЕ КОНЦЕНТРАЦИИ \\ РАДИОНУКЛИДОВ В ДОННЫХ ОТЛОЖЕНИЯХ ВОДОЕМОВ И ПРИБРЕЖНОМ ГРУНТЕ}

\section{Д. Ясайтис, М. Пячулене, А. Гиргждис}

P е $з$ ю м е

Определены концентрации естественных и искусственных радионуклидов в донных отложениях водоемов и прибрежном грунте. Установлено, что концентрация большинства радионуклидов в грунте больше, чем их концентрация в донных отложениях (концентрация ${ }^{40} \mathrm{~K}$ в грунте в среднем достигает 500 Бк/ $\mathrm{M}^{3}$, а в донных отложениях около 200 Бк/ $\mathrm{M}^{3}$ ). Установлена прямая корреляционная связь между всеми естественными радиоизотопами. Коэффициенты корреляции радионуклида искусственного происхождения ${ }^{137} \mathrm{Cs}$ и естественных радионуклидов близки к нулю.

Ключевые слова: ионизирующее излучение, естественные радионуклиды, удельная активность, грунт, почва. 